\title{
Stress, the brain and behavior
}

Citation for published version (APA):

Markus, C. R. (2016). Stress, the brain and behavior: what is the influence of food? Maastricht University. https://doi.org/10.26481/spe.20160916rm

Document status and date:

Published: 16/09/2016

DOI:

10.26481/spe.20160916rm

Document Version:

Publisher's PDF, also known as Version of record

\section{Please check the document version of this publication:}

- A submitted manuscript is the version of the article upon submission and before peer-review. There can be important differences between the submitted version and the official published version of record.

People interested in the research are advised to contact the author for the final version of the publication, or visit the DOI to the publisher's website.

- The final author version and the galley proof are versions of the publication after peer review.

- The final published version features the final layout of the paper including the volume, issue and page numbers.

Link to publication

\footnotetext{
General rights rights.

- You may freely distribute the URL identifying the publication in the public portal. please follow below link for the End User Agreement:

www.umlib.nl/taverne-license

Take down policy

If you believe that this document breaches copyright please contact us at:

repository@maastrichtuniversity.nl

providing details and we will investigate your claim.
}

Copyright and moral rights for the publications made accessible in the public portal are retained by the authors and/or other copyright owners and it is a condition of accessing publications that users recognise and abide by the legal requirements associated with these

- Users may download and print one copy of any publication from the public portal for the purpose of private study or research.

- You may not further distribute the material or use it for any profit-making activity or commercial gain

If the publication is distributed under the terms of Article $25 \mathrm{fa}$ of the Dutch Copyright Act, indicated by the "Taverne" license above, 


\section{Maastricht University}

Prof. Dr. C. Rob Markus

Faculty of Psychology and Neuroscience

Department of Neuropsycholoy \& Psychopharmacology

\section{Stress, the Brain and Behavior; what is the influence of food?}

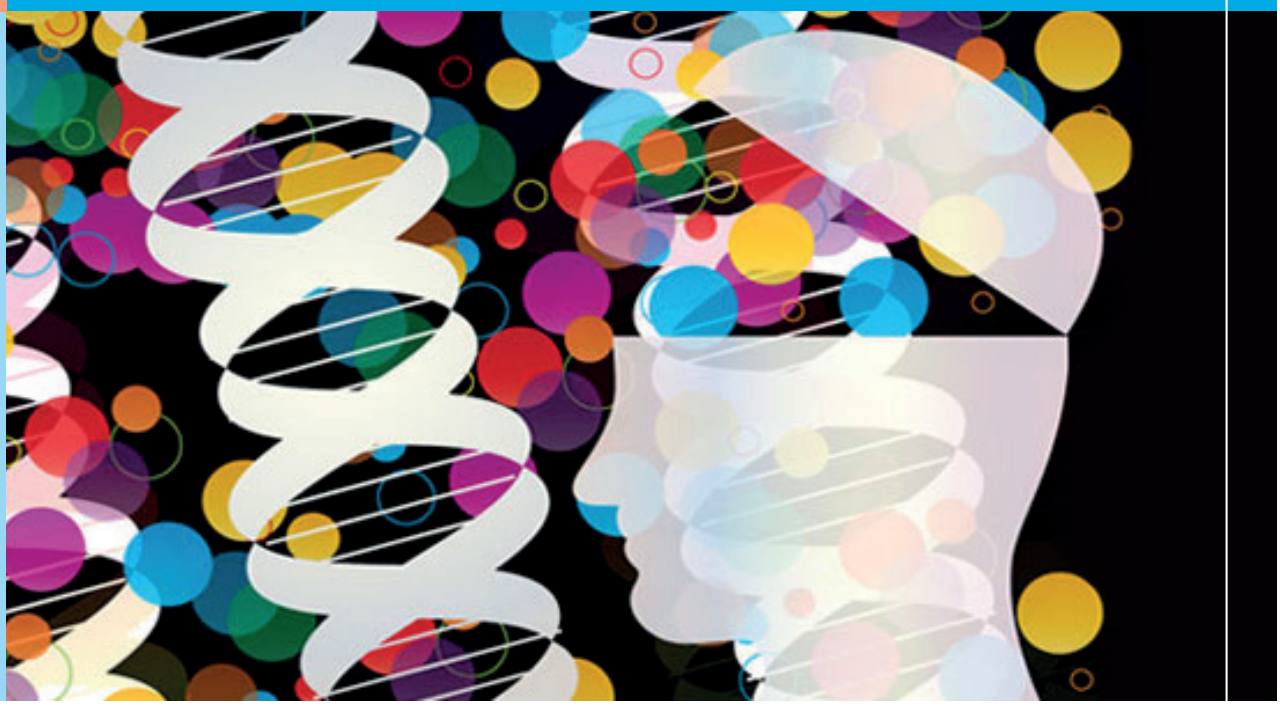




\section{Stress, the Brain and Behavior; what is the influence of food?}

INAUGURAL LECTURE

Chair "Food, the Brain and Behavior", 16 September 2016

Prof. Dr. C. Rob Markus

Faculty of Psychology and Neuroscience; Department of Neuropsychology \&

Psychopharmacology, Maastricht University

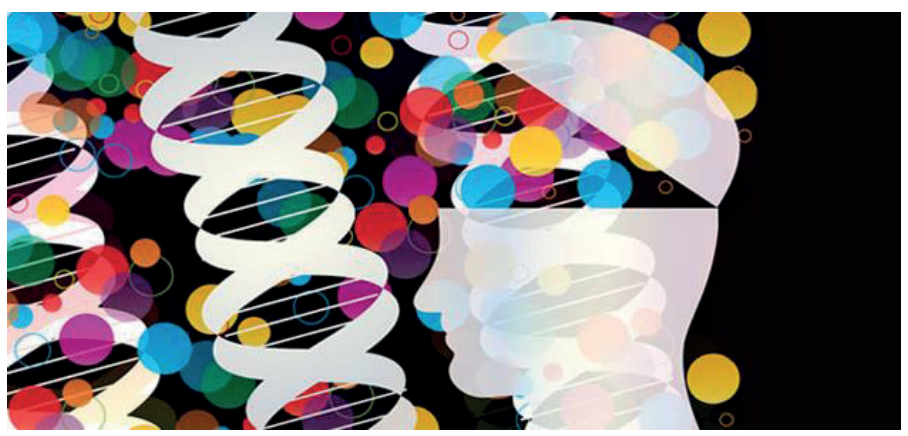

[This text represents the global content, not a copy, of what has been presented during the lecture. The brief introduction and word of thanks that are given during the lecture is not included in this text).

ISBN: 978-90-5681-466-3

NUR: 770 


\section{Stress, the Brain and Behavior}

In a society run by deadlines, the clock, modern technology and numerous other demands and pressures, stress is an unavoidable part of everyday life. When an individual encounters an event that is mentally evaluated or 'appraised' as a difficult to cope with threat to well-being (e.g. (Folkman and Folkman, 1984)), the body initiates a stress response (e.g.(McEwen, 2007)). A stress response will express itself in a physiological as well as cognitive-affective reaction (e.g.(Steptoe et al., 2007)). In the brain, there is a stress-system (hypothalamicpituitary-adrenal axis or HPA) that transfers the perceived stressful event into autonomic and neuroendocrine changes throughout the body that are needed for stress adaptation (see (Ursin and Olff, 1993, Akil and Morano, 1995) for a review). Briefly, the perception of stress first quickly initiates a sympathetic release of stress hormones (norepinephrine from nerve terminals and plasma epinephrine from the adrenal glands) into the blood stream. This increase in stress hormones will then leads to increases in heart rate, blood pressure and blood glucose levels that are all needed for immediate defense or stress adaptation (coping). Upon receiving such fast

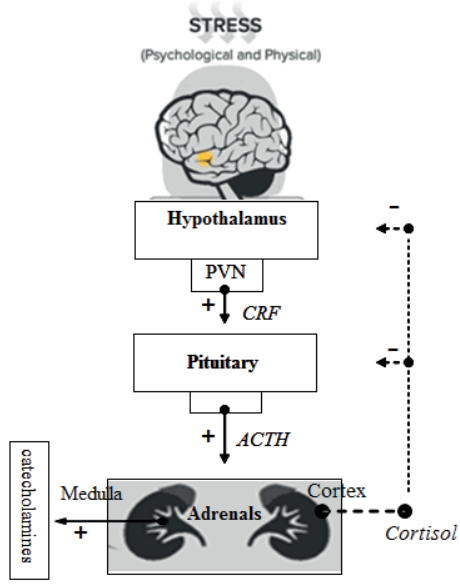

Stress HPA axis

Adapted from; Markus, 2008. Neuromolecular Medicine 10; 247-258 limbic and hormonal stress inputs, additional cell bodies in the brain and periphery glands are then stimulated to release cortisol (from the cortex of the adrenal glands) that, in turn, is needed to restore the internal balance of the highly activated nervous system via a variety of complex feedback actions in the brain (see for a full review (Markus, 2008). 
If a stress response is caused by a brief exposure to danger, then this response is well designed to support us with the necessary energy to cope with the dangerous situation. For instance, if your blood pressure becomes 190/120 because you noticed a predator coming after you during your stay in Africa, then you are not suffering from a disease but you are just showing a normal response meant to save your life. The trouble begins when the body is exposed to stress responses for longer periods of time due to cognitive-emotional worrying (e.g. always trying to be someone else, thinking frustrating things or working under mental load, continuing bad relationships, committing yourself to things you're not up to, and more) which is not uncommon in humans. Such a prolonged exposure to stress and its associated bodily responses will have long-lasting detrimental effects on brain structures and functions that may ultimately lead to a wide-range of different physiological, behavioral and/or psychiatric disorders (e.g. (McEwen and Wingfield, 2003, van Praag, 2004, Steckler et al., 2005)). In this respect, stress is one of the most important leading causes of current psychopathological diseases burden throughout the world and is often associated with severe medical consequences and mortality. The most typical stress-related 'diseases' are moodrelated disorders such as depression and often related eating-, sleep-, and cognitive-attentional disorders.

\section{Stress-proneness; individual differences}

An important feature of both the physiological as well as the affective stress response is that it differs greatly in strength among different individuals as well as across different situations or tasks (e.g. (Boyce and Ellis, 2005, Kudielka et al., 2009)). Two individuals exposed to the same situation may differ substantially in the strength and duration of their stress responses. These inter-individual differences in stress reactivity are assumed to underlie the current existence of a broad variability in stress-illness and/or stress-psychopathology associations 
(e.g.(Boyce and Ellis, 2005, Steckler et al., 2005, Ursin and Olff, 1993)). As illustrated in Figure 1, maladaptive physiological and affective stress reactivity places individuals at a heightened risk for the development of a variety of stress-related disorders, whereas appropriate stress reactivity may act as a resilience factor preventing the development of stress-related psychopathology (e.g. (Feder et al., 2009)).

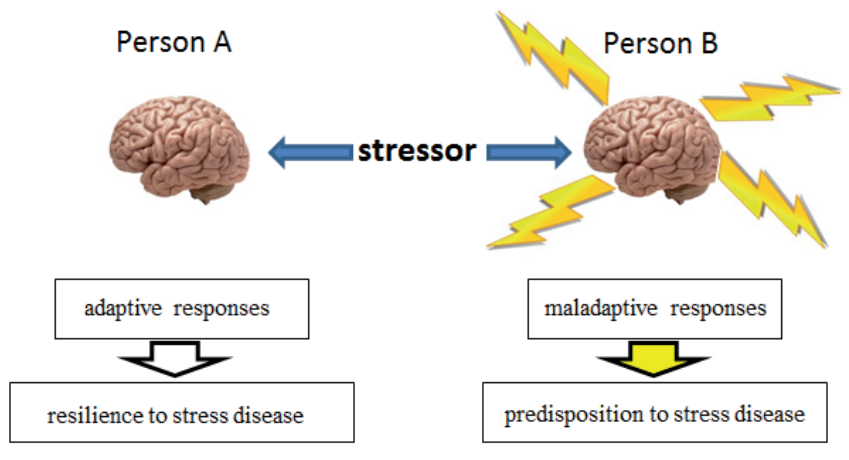

Figure 1. Schematic representation of differences between individuals in stress reactivity and disease susceptibility. In person A (left) adaptive stress responses are initiated after stress exposure, thereby reducing the risk for stress-related psychopathology. Conversely, maladaptive stress responses in person B (right) increases the risk for a variety of dosorders.

Since maladaptive physiological and affective stress responses are involved in a wide range of physiological and psychopathological processes, it is highly important to identify vulnerability factors that contribute to inter-individual differences in stress reactivity and consequent susceptibilities for the development of stress-related disorders (Bartolomucci, 2005). Although there is as yet no complete understanding of the origins of inter-individual differences in physiological and affective stress reactivity, there is now wide acknowledgement that both genetic and cognitive-mental variables are involved (e.g.(Boyce and Ellis, 2005, Markus, 2008, Markus, 2013)). It is therefore my strong conviction that both biological and psychological factors and, in particular, their mutual interactions should be explored in order to reach a complete explanatory model for human (stress-related) diseases. 


\section{Bio-involvement: how genes influence brain resilience}

Genetic factors play an important role in shaping inter-individual differences in stress reactivity (e.g. (Mormede et al., 2002)). Genes are hypothesized to either protect against or increase the likelihood of inadequate physiological and affective stress responsiveness; causing stress resilience in some individuals and leading to psychopathology in others (e.g. (Feder et al., 2009, Belsky and Pluess, 2009, Leigh, 2009)). Genes are able to do this by producing (and controlling) the basic chemical signal-substances in the brain. These so called 'communication substances' or neurotransmitters are the main electro-chemical signals by which the brain's nerve cells communicate; by transferring signals from the one cell to the other cell and selectively altering (enhancing or inhibiting) neural activation. Given that stress reactivity is partly heritable (e.g. (Bartels et al., 2003)) and that the brain neurotransmitter serotonin (5-Hydroxytryptamine or 5-HT) has been most clearly and systematically demonstrated to be involved in stress and a range of stress-related behavioral-affective disorders (e.g. (Graeff et al., 1996, Linthorst, 2005, van Praag, 2004, Markus et al., 2008)); particular attention has been given to the role of genes that may make the brain's serotonergic system vulnerable for stress reactivity and, hence, stress-illness.

Briefly, functionality of the brain serotonin (5-HT) system partly depends on a gene that controls the serotonin transporter (5-HTT) (e.g.(Hariri and Holmes, 2006); which is a monoamine carrier protein that transfers serotonin back into the presynaptic neuron (and, thus, the base for 5-HT neural communication). In the 'promoter' region of this gene, there is a functional differentiation (or a 'variable repeat sequence polymorphism'; abbreviated by 5HTTLPR) that results in a short (S) and a long (L) promotor sequence variant. The S-variant of this 5-HTTLPR genotype is less active than the L-variant, causing lower 5-HT transporter binding and mRNA expression (Heils et al., 1996, Lesch et al., 1996). Consequently; the S- 
allele 5-HTTLPR variant, that is present in $>60 \%$ of the population, is commonly found to promote brain serotonin dysfunction/disruptions and, hence, to increase stress proneness and the risk of developing stress-related affective disorders like depression (e.g. (van Praag, 2004, Hariri and Holmes, 2006, Firk and Markus, 2009, Markus et al., 2008, Markus, 2008, Caspi et al., 2010, Karg et al., 2011, Markus and Capello, 2012, Roy et al., 2014)).

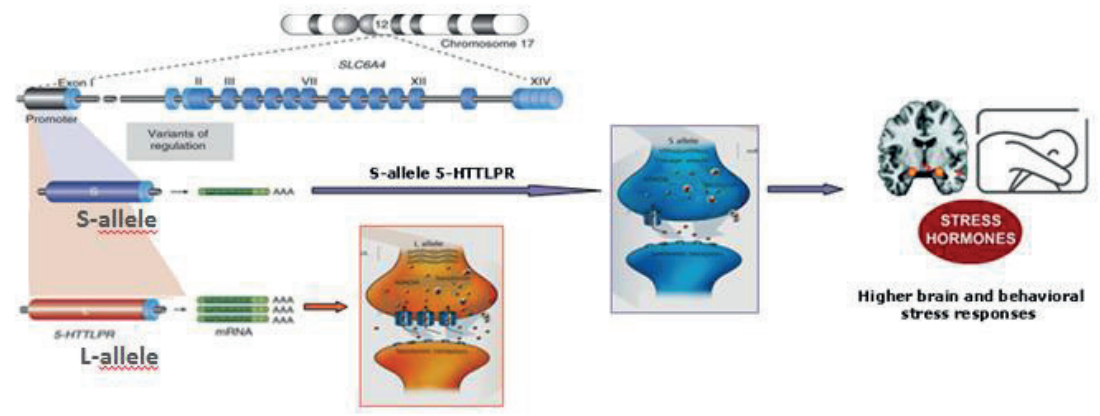

People who carry one or two copies of the S-allele 5HTTLPR gene show stronger activation of the emotional-stress brain network when confronted with fearful and/or other emotionally negative events (e.g.(Munafo et al., 2008, Alexander et al., 2012, Firk et al., 2013, Thomason et al., 2010, Madsen et al., 2016, Fisher et al., 2015, Hariri and Holmes, 2006, Hariri et al., 2005)) as well as increased behavioral, emotional and/or neuroendocrine stress responses (e.g.(Gotlib et al., 2008, Markus and Firk, 2009, Markus and De Raedt, 2011, Verschoor and Markus, 2011, Markus, 2013, Capello and Markus, 2014, Cerit et al., 2013, Way and Taylor, 2010, Dougherty et al., 2010, Firk and Markus, 2009).

Most interesting, and in line with the classic diathesis-stress model, ample recent studies and meta-analyses reveal that the s-allele 5-HTTLPR genotype particularly increases the risk for stress-related affective disorders and other related illnesses in the presence of stressful events (e.g.(Caspi et al., 2010, Caspi et al., 2003, Wankerl et al., 2010, Karg et al., 2011, Miller et 
al., 2013, Markus, 2013)). A first source of compelling evidence for this apparent Gene $x$ Environment (stress exposure) interaction on stress-related disorders came from a seminal study by Caspi and colleagues (Caspi et al., 2003). Specifically, in this prospective longitudinal study it was reported that individuals carrying the S-allele of the 5-HTTLPR gene responded more readily to stressful life events with depression (and suicide) symptoms than individuals with the L-genotype. Since then a series of other epidemiological studies was performed of which most were able to replicate Caspi's initial findings (see for reviews; (Uher and McGuffin, 2008, Karg et al., 2011)). In addition, many experimental imaging as well as acute stress exposure studies confirmed the involvement of the S-allele 5-HTTLPR genotype in heightened stress responsiveness (e.g.(Alexander et al., 2012, Munafo et al., 2008, Gotlib et al., 2008, Mueller et al., 2010, Markus and De Raedt, 2011, Way and Taylor, 2010, Firk et al., 2013).

\section{In need for additional research}

Although a broad range of epidemiological and acute stress exposure studies have thus supported the notion that a gene (the S-allele 5-HTTLPR genotype) meaningfully promotes stress responsiveness and, hence, contributes to the risk of developing stress-related affective disorders; there still are studies that could only partly or not at all replicate this gene (5HTTLPR) x Stress exposure interactive effects on the development of affective disorders (Uher and McGuffin, 2008, Karg et al., 2011, Sharpley et al., 2014). Such inconsistencies in findings make it more likely that genes are (just) contributing instead of determining factors in the emergence of stress-related complaints or diseases (Markus, 2013). Consequently besides genes, there must be additional factors causing the large inter-individual differences in stress reactivity and disease susceptibility. After all, not all carriers of the S-allele 5-HTTLPR suffer from affective and/or stress-related disorders. Obviously, as befits a true psychologist, 
we cannot blame our genes only for becoming affected under stress; there should be a crucial role for the way we perceive and process stressful experiences and its emotional impact. Reaching a workable biopsychological model for the development of stress-related psychopathological illness is one of the most desirable goals of today's biopsychological research. The current chair aims to further fulfill this need by focusing on two major research topics: 1) how genetic and cognitive stress-vulnerability may mutually promote stress-related psychopathology and 2) to discover how food may intervene in such genetic and stressvulnerability interactions. In addition, particularly relating to the latter topic, a third (sub) aim is to find ways of better informing the broader public about the facts and especially myths that exist about the influence of food on brain and behavior.

\section{Aim 1: Genes, stress and psychopathology: where does cognition come into play?}

As mentioned earlier, the inconsistencies in findings regarding gene, brain and stress interactions in the development of stress-related illnesses might well be explained by the relative lack of consideration for moderating cognitive-psychological factors. According to the generally accepted cognitive vulnerability-transactional stress model of negative affectivity and/or depression (Folkman and Folkman, 1984), the harmfulness of a stressor is primarily determined by the meaning and importance that we assign to it. In fact, an event becomes especially stressful when 1) it is experienced as personally relevant and highly (emotionally) threatening ('primary appraisal') and 2) when we do not have (belief in) adequate abilities/resources to cope with the stressor ('secondary appraisal') (Roberts et al., 1987, Folkman and Folkman, 1984, Gunthert et al., 1999). 


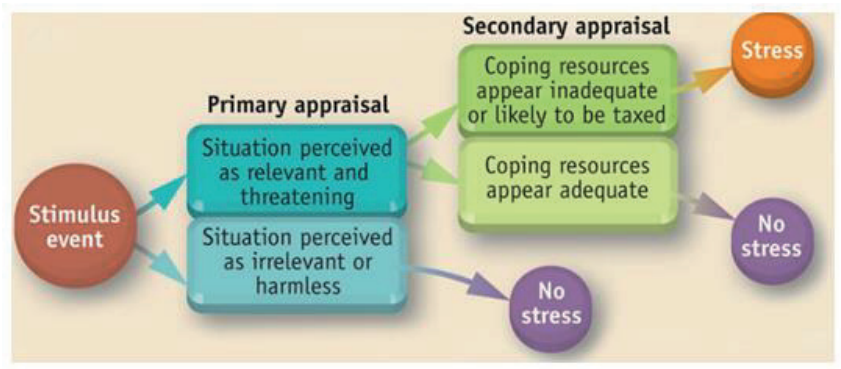

Cognitive appraisal model: evaluation of the stressor actively mediates the relationship between the stress imput (stressor perception) and response output (stress response) (Lazarus \& Folkman, 1984, 1994)

One's evaluation of how stressful a threatening event might become, depends largely on the possession of, and belief in, adequate coping strategies (self-efficacy). This 'belief in selfefficacy' is rather strongly influenced by personality (trait) characteristics that already emerge early in life and are continuously changing during meaningful person-environmental interactions across the lifespan. In particular personality characteristics that expresses high emotional vulnerability traits (e.g. neuroticism, trait anxiety) are thought to be most strongly related to stress proneness (e.g.(van Praag, 2004, Markus et al., 1998, Watson and Clark, 1984)). For instance, individuals with high trait neuroticism are more vulnerable to experience stress (Watson and Clark, 1984, van Praag, 2004, Markus, 2013), have low expectations for self-efficacy and/or possess less-adaptive coping strategies (Gunthert et al., 1999, Penley et al., 2002) and are most vulnerable to develop stress-related emotional-behavioral disorders (Roberts and Kendler, 1999, van Praag, 2004). So whether or not an event might become highly stressful and/or will promote the development of stress-related diseases depends on biological (e.g. s-allele gene) as well as cognitive-emotional (personality factors such as neuroticism) vulnerability factors. 


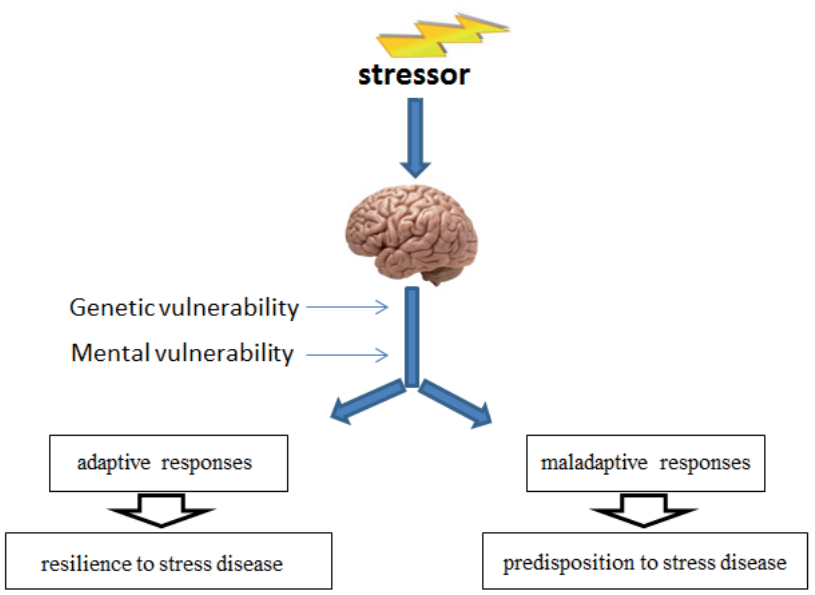

Figure 2. Stress reactivity and disease susceptibility is modulated by both genetic brain vulnerabilities (e.g. S-allele 5-HTTLPR) and mental (cognitive-emotional) vulnerabilities (e.g. neuroticism).

Whereas both genetic and cognitive vulnerability factors could in isolation promote stressrelated disorders, it is my strong conviction that this risk becomes especially profound when carrying both vulnerability factors in combination. For instance, perceiving an event as threatening (by cognitive appraisal) will lead to an enhanced brain serotonin (5-HT) and stressarousal (HPA) response to provide psycho-physiological stress adaptation (e.g. fight and flight behavior) (e.g.(Dickerson and Kemeny, 2004, van Praag, 2004, Markus, 2008)). However, when experiencing continuous stress (e.g. as a function of trait neuroticism or negativeruminative thinking patterns) this causes long-lasting increases in stress activation (and stress hormones) that will ultimately change or 'imbalance' the biological system by reducing 5 -HT sensitivity and HPA function; thereby further increasing the risk for developing stress-related psychopathology (van Praag, 2004, Maes et al., 1995, Markus et al., 2000, Jans et al., 2007, Zoccola and Dickerson, 2012, Markus et al., 1999, Markus et al., 1998). Especially in combination with a genetic (s-allele 5-HTTLPR) vulnerability factor, this type of process is expected to further exacerbate the negative effects of long-lasting stress experiences; because 
this genotype already promotes maladaptive brain 5-HT sensitization (to compensate for the lower 5-HTT expression; (David et al., 2005, Markus and De Raedt, 2011, Jans et al., 2007) and HPA stress responsiveness (Karg et al., 2011, Miller et al., 2012). Based on these findings and suggestions, it is most likely that not genes or psychological factors alone, but especially the combined presence of cognitive as well as genetic vulnerability factors will most profoundly increase the risk for developing stress-related psychopathology.

Surprisingly, most studies focusing on such gene-stress-affective disorder relationships have thus far measured stress by just counting the number of self-reported stressful life events without meaningful consideration of possible cognitive moderators that determine the emotional impact of such events. Only a few recent studies, including our own work, provide first indirect support for such cognitive vulnerabilities mediating the 5-HTTLPR genotype by life event effects on depression symptomatology. For example, in a recent study conducted in our lab S-allele 5-HTTLPR carriers exhibited vulnerability to depression exclusively when they also reported exposure to high impact events and had high neuroticism scores (Markus, 2013).

Until now I have mainly focused on the importance of the combined presence of genetic, personal and environmental vulnerability factors for the development of affective disorders like depression. But as we know, there are many more behaviors known to be affected by stress, such as, for example, our eating- or sleep behavior but also our levels of attention/cognitive performance. For instance, as concerns eating, people often crave highcalorie foods when feeling stressed or facing difficult emotional problems in daily life, and this 'emotional eating' is thought to be one of the most important causes for weight gain and obesity (e.g.(Markus and Capello, 2012, Schepers and Markus, 2015, Mellbin and Vuille, 1989a, Mellbin and Vuille, 1989b, Kivimaki et al., 2006). In spite of intensive research from 
both neurobiological and cognitive disciplines, the cause of emotional (over-)eating has not yet been elucidated while overweight and obesity still form a major problem for society as their incidence is still growing. Some of our own first studies in this direction indeed suggest that especially the combination of genetic (5-HTTLPR) and cognitive stress-vulnerabilities might promote emotional eating patterns under stress (Markus and Capello, 2012, Markus et al., 2015, Schepers and Markus, 2015). Comparable interactive effects of genetic and cognitive vulnerabilities and stress have been proposed for stress-related sleep-complaints (Brummett et al., 2007, van Dalfsen and Markus, 2015) or for the severity of ADHD symptoms under stress (van der Meer et al., 2015, Morgan et al., 2016).

To summarize; a first aim of the current chair is to further explore the singular and interactive effects of bio-genetic (5HTTLPR), cognitive (neuroticism/rumination) and environmental factors (frequency of harmful life events) vulnerability factors on the onset and course of stress-related illnesses.

\section{Aim 2: can food influence stress vulnerability?}

Another interest that I have since I did my first $\mathrm{PhD}$ work in this area is the potential role of food on the brain and stress-related dysfunction. As previously described; dysfunctional brain serotonin (5-HT) neurotransmitter synthesis and release is one of the important biological vulnerability factors for high stress-sensitivity and the likelihood of developing stress-related psychopathology. Thus, if we could manipulate/restore 5-HT functioning in the brain this would have great impact on brain function/dysfunction and related behaviors. Interestingly, the synthesis/production of 5-HT in the brain is solely dependent on the availability of its dietary amino acid precursor tryptophan (TRP) in the blood. Tryptophan is a so called 'essential amino acid'; meaning that the body cannot produce it by itself and it thus needs to be obtained from 
food (from dietary proteins). In other words; if we do not obtain TRP from food, brain 5-HT will rapidly fall below functional need and will ultimately lead to serious brain and behavioral dysfunction. Since brain 5-HT synthesis is solely controlled by the dietary supply of its precursor TRP, 5-HT function can be changed by manipulating the diet in such a way that there is more (or less) available TRP in the blood for uptake into the brain. A rise in plasma (and brain) TRP can be accomplished by increasing dietary intake of TRP and/or by increasing the amount of sugar/carbohydrates in food. Both factors are shown to lead to a rise in plasma TRP relative to the sum of other large neutral amino acids (LNAA's) that compete with TRP for transport into the brain (Fernstrom, 1990, Wurtman et al., 2003, Markus, 2008). Sugar and carbohydrates do not contain TRP, but cause an increase in brain TRP (and thus 5HT) by evoking an insulin response that sends the LNAA's (except for TRP) into peripheral tissue (via this route increasing the plasma TRP/LNAA ratio).

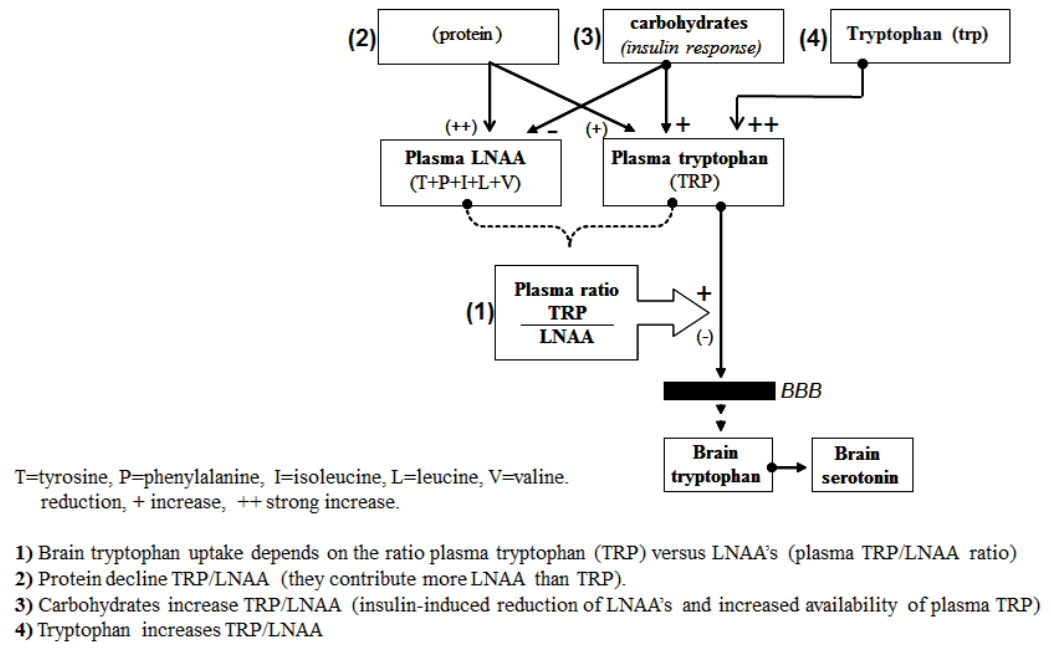

Adapted from; Markus, 2008. Neuromolecular Medicine 10; 247-258 
Contrary, although containing low percentages of TRP, proteins are usually found to decline plasma TRP/LNAA ratio's because they contribute proportionately more LNAA's. Appealing exceptions were reported for milk-derived (alpha-lactalbumin) proteins that caused large increases in plasma TRP/LNAA and brain 5-HT due to their higher TRP concentrations (Markus et al., 2002, Markus et al., 2005, Markus et al., 2008, Markus et al., 2000, Orosco et al., 2004).

This 'plasma amino acid to brain dependence' is the same route as by which the 5-HT system signals brain (hypothalamic) areas to promote sugar and/or carbohydrate intake when 5-HT levels are too low (Simansky, 1996, Leibowitz and Alexander, 1998). In fact, there is a reciprocal relationship between the intake of proteins and carbohydrates and brain 5-HT; the intake of carbohydrates may inhibit further carbohydrate consumption by increases in plasma TRP/LNAA and brain 5-HT function, whereas protein consumption normally has the opposite effect by lowering the plasma TRP/LNAA ratio (Wurtman, 1984, Wurtman and Wurtman, 1984). All such dietary effects on plasma and brain TRP and 5-HT synthesis are well documented in animal and human studies (Wurtman et al., 2003, Fernstrom, 1990, Markus et al., 1998, Markus, 2008).

Interest in the relationship between food, plasma TRP/LNAA and brain 5-HT synthesis on the one hand, and between 5-HT, stress and its effects on mood/affectivity on the other hand has led to the completion of a variety of dietary studies carried out during the last decades. Many of these studies from our own, but also studies from other labs, have reported positive effects of carbohydrate-rich and/or TRP containing/enhancing diets on mood and/or stress sensitivity (Spring et al., 1987, Rogers, 1995, Christensen, 1997, Bellisle et al., 1998, Markus, 2008, Markus et al., 2008, Wurtman, 2011, Markus et al., 2010, Markus et al., 2000, Markus et al., 2002), and recent studies reveal that this is more frequently reported in persons possessing the 
earlier discussed cognitive and/or genetic (s-allele 5-HTTLPR) stress-vulnerability factors (Markus et al., 1998, Markus et al., 1999, Markus, 2008, Markus and Firk, 2009, Markus and De Raedt, 2011, Cerit et al., 2013, Capello and Markus, 2014). The other way around, TRP depletion is found to have the opposite effect in these vulnerable subjects (Neumeister et al., 2002, Neumeister et al., 2006, Firk and Markus, 2009).

Based on these findings, it is an intriguing possibility that 5-HT enhancing dietary manipulations may particularly interfere with the likelihood of developing stress-related disorders in those that possess both genetic (5-HTTLPR) and cognitive stress vulnerability factors in combination. Such research has only been recently started and already reveal some support for beneficial effects of 5-HT enhancing foods on stress related behavior; including effects on emotional-eating (Markus et al., 2015, Schepers and Markus, 2015), stressresponsiveness (Markus et al., 2012, Cerit et al., 2013, Capello and Markus, 2014) and sleep quality (van Dalfsen and Markus, 2015). The current chair aims to continue and intensify further research on this topic.

\section{Sub-Aim: Informing the community about food-brain-behavior relations}

Since food and/or changes in diet-constitution are, under particular circumstances, capable of influencing brain function and related behavior, there has been a growing scientific and societal interest in the way nutrients may impact performance and social-emotional wellbeing. Besides the previous described effects of tryptophan-enhancing foods (carbs, TRP or

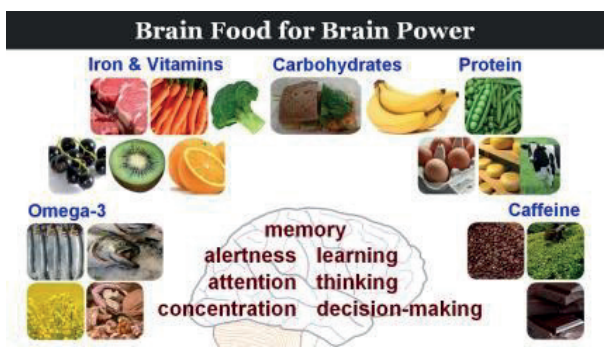

certain TRP-rich milk-derived proteins), other examples can be given ranging from, for example; 1) the beneficial effects of polyunsaturated fatty acids (e.g. oils from fish, nuts like omega-3) 
on mood, depression symptomatology and/or cognitive-attentional-processing, 2) the effects of anti-oxidative foods like fruit, vegetables and/or vitamins on cognitive performance, intellectual ability and intelligence, 3) influence of multivitamins and/or minerals (zinc, copper, magnesium) on aggressive behavior, to 4) the mental boosting effects of certain herbs and/or botanicals like Ginkgo biloba or St John's-wort (Hypericum perforatum) on memory, intellectual capacity or depression.

In particular the suggested positive effects of foods or nutritional supplements on brain and behaviour have been picked up by the food industry, and has led to the launching of a wide range of often expensive natural (extracted) products on the nutraceutical market, with the promise that they will boost healthy mental processes and/or will reduce psychopathological disorders or symptoms involving depression, ADHD and/or memory loss.

Although some of these food-behaviour assumptions or claims may reflect sound (biochemical) theoretical mechanisms of actions that are described and/or supported by the scientific literature (e,g, involving anti-oxidation, brain energy, cell-structures and/or neurocommunication), most are based on just one or few (often methodologically-limited) studies and are seldom supported by meta-analyses of findings from studies with randomizedcontrolled-designs (RCT). For the broader public, it is however often hard to distinguish between good and bad scientific research and practice, making it even harder to discern facts from myths. Moreover, media and press (and even biased scientists) may sometimes falsely interpret, or even misuse, scientific findings of which the general public/consumers are not aware. I will restrict myself by giving just two most illustrative examples to show how scientific data can easily be misinterpreted and cause strong, but scientifically unsupported, beliefs about the effects of food in the broader public. The first example will be about food (sugar) addiction and obesity, and the second about food and ADHD symptoms. 
Myth example-1: Sugar is an addictive drug that causes a worldwide increase in obesity.

With the worldwide increasing prevalence of overweight and its severe health consequences, the concept of 'food addiction' has gained popularity; not only in the lay public but also among food researchers, and in nutrition practices. In most recent discussions about healththreatening snacks or foods, particularly the sugary foods get a lot of attention because of their (by some) assumed addictive potential. This assumption is however not based on scientific evidence from studies with humans but on results from a few animal studies showing that sucrose intake in mice or rats can cause short moments of sugar bingeing (even without affecting weight) and can stimulate brain dopaminergic pathways. Since dopamine is also increased by addictive drugs, like for instance cocaine, this led to the false conclusion by some researchers that sugar is addictive; a message that was copied and presented to the broader public by the media and press. This all led to the a situation in which now many people believe that obesity is more strongly caused by sugar than by other palatable energydense foods due to its addictive properties.

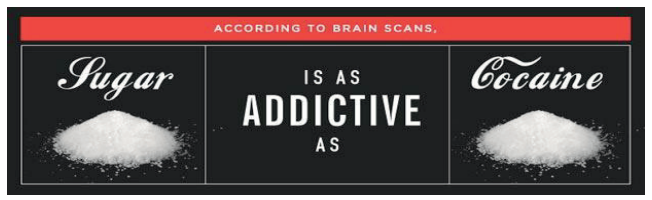

The fact that sugar intake enhances dopaminergic activity in rats does however not justify the conclusion that it is thereby addictive since the dopaminergic reward system is not only activated in response to addictive stimuli or substances. Instead, the brain's dopaminergic reward circuit is stimulated in lots of pleasurable situations that are not addictive, like when we watch nice events, when we win a price, when we listen to nice music or are in love (Benton, 2010, Benton and Young, 2016). Furthermore, food-initiated changes in the brain have been shown to strongly differ from the drug-related changes (Benton, 2010, Choo and Sievenpiper, 2015, Benton and Young, 2016, Ziauddeen and Fletcher, 2013b). 
Finally, there is a wealth of evidence from reviews and meta-analyses (only evaluating wellcontrolled dietary human studies) clearly showing that sugar does not contribute to weightgain more so than other sources of energy in the diet (e.g. (Hebebrand et al., 2014, Ziauddeen et al., 2013, Ziauddeen and Fletcher, 2013a, Markus et al., Submitted, Wittekind and Walton, 2014). Instead, there is clear scientific consensus that "food addiction" (and its role in weight gain) might be better explained by "eating dependence"; emphasizing that problematic eating behavior and related weight gain is not caused by a specific food, but rather is the result of unique individual experiences with food and eating. Despite all this evidence, such messages or contra-evidence are however barely picked up by the press/media making it hard for the broader public to correctly inform themselves.

Myth example 2: Food colorants, artificial sweeteners and sugar cause ADHD

There is a strong societal belief that artificial sweeteners, sugar and/or food colorants might cause hyperactivity and/or attentional problems as seen in children with ADHD. Some scientists have investigated this by either removing artificial elements from the food (elimination diets) or by increasing the intake of certain nutrients (challenge tests). Actually, many of these studies refer to a very old (methodologically weak) study in which a diet without artificial sweet-flavors and colorants (the Feingold diet) was claimed to reduce ADHD symptoms in children (Feingold, 1975b, Feingold, 1975a). However, support for this was only found in a minority of studies that were all methodologically weak (few participants, not blinded and/or randomized, uncontrolled dietary manipulations, bad diagnostic classifications and psychometric qualities of outcome measures, etc), whereas meta-analyses or reviews including well-controlled RCT experiments could not find any significant effect of such dietary manipulations or show rather mixed results (Wolraich et al., 1995, Bateman et 
al., 2004, Cruz and Bahna, 2006). Nevertheless, parents even today are misled by information in the media, press that their children get "hyperactive" after eating a lot of sugar, artificial sweeteners and/or food colorants; even though high quality studies clearly reveal that such increases in hyperactivity are more likely caused by the circumstances associated with candy intake (birthday parties, holidays) instead of the food constituent itself.
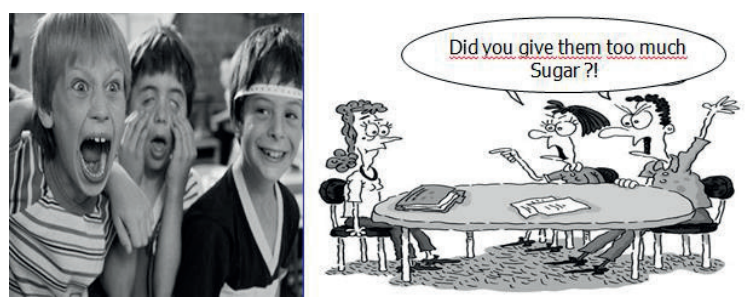

A rather illustrative RCT study (just to pick one...) is the one in which a sufficient

number of 'believing'-parents (believing that sugar might increase ADHD-related behavior) were invited with their sons to participate in a controlled laboratory experiment. They were told that the aim of the study was to observe the level of hyperactive behavior of their children after consumption of 'sugar' compared to a placebo beverage (PLC). In fact, what the parents did not know, was that all children were given the PLC drink. So, one half of the parents believed that their children received sugar drink whereas this actually was placebo, while the other half were correctly informed that their children received the PLC drink (Hoover and Milich, 1994). Thirty minutes after all the children consumed the placebo drink, the parents and an expert-observer who was blind to the conditions observed the children's behavior for signs of hyperactivity/impulsivity. Results revealed that only the parents who believed that their children consumed sugar (while they actually did not) reported significantly more/stronger ADHD behavior than parents (or expert-observers) that knew that children received PLC. 
Thus, again, even though there is clear scientific consensus that ADHD symptoms are not meaningfully promoted by particular foods, this apparently is not interesting enough to be noticed and/or correctly interpreted by the press/media and broader public.

The final (third) aim of the current chair is to inform the broader public about facts and myths that exist regarding the influence of foods and/or macronutrients on the brain and behavior. One important starting point might be to convince society/the broader public that the scientific truth is not likely found in one uncontrolled study or on the internet, but at least needs careful scientific evaluation of the s average findings of multiple and only well-conducted RCT

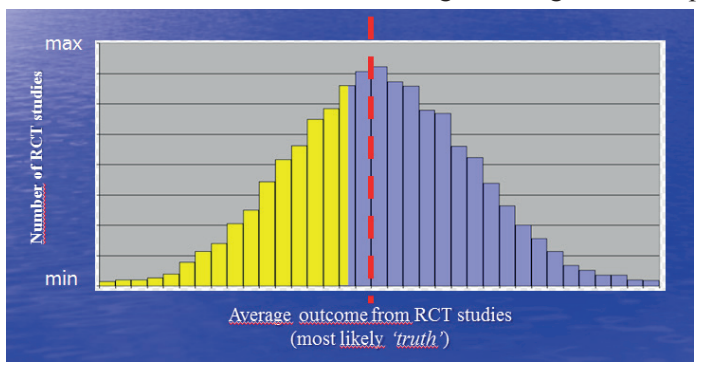
studies (e.g. preferably by using meta-analyses).

Today, new insights from neuropsychology and biological psychology lead to the development of exciting and promising new biopsychological models that will hopefully enable us to better understand the onset and course of stress-related illness and psychopathology. In addition, research findings from the emerging interdisciplinary field of Nutritional Neuroscience might even further elaborate such new insights and models and will hopefully lead to the development of new innovative research lines and/or treatment strategies for stress-related disorders. It is my strong wish that the current chair will contribute to this endeavor.

Rob Markus, 16 September, 2016 


\section{References}

AKIL, H. A. \& MORANO, M. I. 1995. Stress, New York, Raven Press.

ALEXANDER, N., KLUCKEN, T., KOPPE, G., OSINSKY, R., WALTER, B., VAITL, D., SAMMER, G., STARK, R. \& HENNIG, J. 2012. Interaction of the serotonin transporter-linked polymorphic region and environmental adversity: increased amygdala-hypothalamus connectivity as a potential mechanism linking neural and endocrine hyperreactivity. Biol Psychiatry, 72, 49-56.

BARTELS, M., VAN DEN BERG, M., SLUYTER, F., BOOMSMA, D. I. \& DE GEUS, E. J. 2003. Heritability of cortisol levels: review and simultaneous analysis of twin studies. Psychoneuroendocrinology, 28, 121-37.

BARTOLOMUCCI, A. 2005. Resource loss and stress-related disease: is there a link? Med Sci Monit, 11, RA147-154.

BATEMAN, B., WARNER, J. O., HUTCHINSON, E., DEAN, T., ROWLANDSON, P., GANT, C., GRUNDY, J., FITZGERALD, C. \& STEVENSON, J. 2004. The effects of a double blind, placebo controlled, artificial food colourings and benzoate preservative challenge on hyperactivity in a general population sample of preschool children. Arch Dis Child, 89, 506-11.

BELLISLE, F., BLUNDELL, J. E., DYE, L., FANTINO, M., FERN, E., FLETCHER, R. J., LAMBERT, J., ROBERFROID, M., SPECTER, S., WESTENHOFER, J. \& WESTERTERP-PLANTENGA, M. S. 1998. Functional food science and behaviour and psychological functions. Br J Nutr, 80 Suppl 1, S173-93.

BELSKY, J. \& PLUESS, M. 2009. Beyond diathesis stress: differential susceptibility to environmental influences. Psychol Bull, 135, 885-908.

BENTON, D. 2010. The plausibility of sugar addiction and its role in obesity and eating disorders. Clin Nutr, 29, 288-303.

BENTON, D. \& YOUNG, H. A. 2016. A meta-analysis of the relationship between brain dopamine receptors and obesity: a matter of changes in behavior rather than food addiction? Int J Obes (Lond), 40 Suppl 1, S12-21.

BOYCE, W. T. \& ELLIS, B. J. 2005. Biological sensitivity to context: I. An evolutionarydevelopmental theory of the origins and functions of stress reactivity. Dev Psychopathol, 17, 271-301.

BRUMMETT, B. H., KRYSTAL, A. D., ASHLEY-KOCH, A., KUHN, C. M., ZUCHNER, S., SIEGLER, I. C., BAREFOOT, J. C., BALlARD, E. L., GWYTHER, L. P. \& WILLIAMS, R. B. 2007. Sleep quality varies as a function of 5-HTTLPR genotype and stress. Psychosom Med, 69, 621-4.

CAPELLO, A. E. \& MARKUS, C. R. 2014. Effect of sub chronic tryptophan supplementation on stress-induced cortisol and appetite in subjects differing in 5HTTLPR genotype and trait neuroticism. Psychoneuroendocrinology, 45, 96-107.

CASPI, A., HARIRI, A. R., HOLMES, A., UHER, R. \& MOFFITT, T. E. 2010. Genetic sensitivity to the environment: the case of the serotonin transporter gene and its implications for studying complex diseases and traits. Am J Psychiatry, 167, 509-27.

CASPI, A., SUGDEN, K., MOFFITT, T. E., TAYLOR, A., CRAIG, I. W., HARRINGTON, H., MCCLAY, J., MILL, J., MARTIN, J., BRAITHWAITE, A. \& POULTON, R. 2003. Influence of life stress on depression: moderation by a polymorphism in the 5 HTT gene. Science, 301, 386-9.

CERIT, H., JANS, L. A. \& VAN DER DOES, W. 2013. The effect of tryptophan on the cortisol response to social stress is modulated by the 5-HTTLPR genotype. Psychoneuroendocrinology, 38, 201-8. 
CHOO, V. L. \& SIEVENPIPER, J. L. 2015. The ecologic validity of fructose feeding trials: supraphysiological feeding of fructose in human trials requires careful consideration when drawing conclusions on cardiometabolic risk. Front Nutr, 2, 12.

CHRISTENSEN, L. 1997. The effect of carbohydrates on affect. Nutrition, 13, 503-14.

CRUZ, N. V. \& BAHNA, S. L. 2006. Do food or additives cause behavior disorders? Pediatr Ann, 35, 744-5, 748-54.

DAVID, S. P., MURTHY, N. V., RABINER, E. A., MUNAFO, M. R., JOHNSTONE, E. C., JACOB, R., WALTON, R. T. \& GRASBY, P. M. 2005. A functional genetic variation of the serotonin $(5-\mathrm{HT})$ transporter affects 5-HT1A receptor binding in humans. $J$ Neurosci, 25, 2586-90.

DICKERSON, S. S. \& KEMENY, M. E. 2004. Acute stressors and cortisol responses: a theoretical integration and synthesis of laboratory research. Psychol Bull, 130, 355-91.

DOUGHERTY, L. R., KLEIN, D. N., CONGDON, E., CANLI, T. \& HAYDEN, E. P. 2010. Interaction between 5-HTTLPR and BDNF Val66Met polymorphisms on HPA axis reactivity in preschoolers. Biol Psychol, 83, 93-100.

FEDER, A., NESTLER, E. J. \& CHARNEY, D. S. 2009. Psychobiology and molecular genetics of resilience. Nat Rev Neurosci, 10, 446-57.

FEINGOLD, B. F. 1975a. Food additives in clinical medicine. Int J Dermatol, 14, 112-4.

FEINGOLD, B. F. 1975b. Hyperkinesis and learning disabilities linked to artificial food flavors and colors. Am J Nurs, 75, 797-803.

FERNSTROM, J. D. 1990. Aromatic amino acids and monoamine synthesis in the central nervous system: influence of the diet. J Nutr Biochem, 1, 508-17.

FIRK, C. \& MARKUS, C. R. 2009. Differential effects of 5-HTTLPR genotypes on mood, memory, and attention bias following acute tryptophan depletion and stress exposure. Psychopharmacology (Berl), 203, 805-18.

FIRK, C., SIEP, N. \& MARKUS, C. R. 2013. Serotonin transporter genotype modulates cognitive reappraisal of negative emotions: a functional magnetic resonance imaging study. Soc Cogn Affect Neurosci, 8, 247-58.

FISHER, P. M., GRADY, C. L., MADSEN, M. K., STROTHER, S. C. \& KNUDSEN, G. M. 2015. 5-HTTLPR differentially predicts brain network responses to emotional faces. Hum Brain Mapp, 36, 2842-51.

FOLKMAN, R. S. \& FOLKMAN, S. 1984. Stress, appraisal and coping, New York, NY, Springer Publishing Company Inc.

GOTLIB, I. H., JOORMANN, J., MINOR, K. L. \& HALLMAYER, J. 2008. HPA axis reactivity: a mechanism underlying the associations among 5-HTTLPR, stress, and depression. Biol Psychiatry, 63, 847-51.

GRAEFF, F. G., GUIMARAES, F. S., DE ANDRADE, T. G. \& DEAKIN, J. F. 1996. Role of 5-HT in stress, anxiety, and depression. Pharmacol Biochem Behav, 54, 129-41.

GUNTHERT, K. C., COHEN, L. H. \& ARMELI, S. 1999. The role of neuroticism in daily stress and coping. J Pers Soc Psychol, 77, 1087-100.

HARIRI, A. R., DRABANT, E. M., MUNOZ, K. E., KOLACHANA, B. S., MATTAY, V. S., EGAN, M. F. \& WEINBERGER, D. R. 2005. A susceptibility gene for affective disorders and the response of the human amygdala. Arch Gen Psychiatry, 62, 146-52.

HARIRI, A. R. \& HOLMES, A. 2006. Genetics of emotional regulation: the role of the serotonin transporter in neural function. Trends Cogn Sci, 10, 182-91.

HEBEBRAND, J., ALBAYRAK, O., ADAN, R., ANTEL, J., DIEGUEZ, C., DE JONG, J., LENG, G., MENZIES, J., MERCER, J. G., MURPHY, M., VAN DER PLASSE, G. \& DICKSON, S. L. 2014. "Eating addiction", rather than "food addiction", better captures addictive-like eating behavior. Neurosci Biobehav Rev, 47, 295-306. 
HEILS, A., TEUFEL, A., PETRI, S., STOBER, G., RIEDERER, P., BENGEL, D. \& LESCH, K. P. 1996. Allelic variation of human serotonin transporter gene expression. $J$ Neurochem, 66, 2621-4.

HOOVER, D. W. \& MILICH, R. 1994. Effects of sugar ingestion expectancies on motherchild interactions. J Abnorm Child Psychol, 22, 501-15.

JANS, L. A., RIEDEL, W. J., MARKUS, C. R. \& BLOKLAND, A. 2007. Serotonergic vulnerability and depression: assumptions, experimental evidence and implications. Mol Psychiatry, 12, 522-43.

KARG, K., BURMEISTER, M., SHEDDEN, K. \& SEN, S. 2011. The serotonin transporter promoter variant (5-HTTLPR), stress, and depression meta-analysis revisited: evidence of genetic moderation. Arch Gen Psychiatry, 68, 444-54.

KIVIMAKI, M., HEAD, J., FERRIE, J. E., SHIPLEY, M. J., BRUNNER, E., VAHTERA, J. \& MARMOT, M. G. 2006. Work stress, weight gain and weight loss: evidence for bidirectional effects of job strain on body mass index in the Whitehall II study. Int $J$ Obes (Lond), 30, 982-7.

KUDIELKA, B. M., HELLHAMMER, D. H. \& WUST, S. 2009. Why do we respond so differently? Reviewing determinants of human salivary cortisol responses to challenge. Psychoneuroendocrinology, 34, 2-18.

LEIBOWITZ, S. F. \& ALEXANDER, J. T. 1998. Hypothalamic serotonin in control of eating behavior, meal size, and body weight. Biol Psychiatry, 44, 851-64.

LEIGH, H. 2009. A proposal for a new multiaxial model of psychiatric diagnosis. A continuum-based patient model derived from evolutionary developmental geneenvironment interaction. Psychopathology, 42, 1-10.

LESCH, K. P., BENGEL, D., HEILS, A., SABOL, S. Z., GREENBERG, B. D., PETRI, S., BENJAMIN, J., MUlleR, C. R., HAMER, D. H. \& MURPHY, D. L. 1996. Association of anxiety-related traits with a polymorphism in the serotonin transporter gene regulatory region. Science, 274, 1527-31.

LINTHORST, A. C. 2005. Interactions between corticotropin-releasing hormone and serotonin: implications for the aetiology and treatment of anxiety disorders. Handb Exp Pharmacol, 181-204.

MADSEN, M. K., MC MAHON, B., ANDERSEN, S. B., SIEBNER, H. R., KNUDSEN, G. M. \& FISHER, P. M. 2016. Threat-related amygdala functional connectivity is associated with 5-HTTLPR genotype and neuroticism. Soc Cogn Affect Neurosci, 11, 140-9.

MAES, M., MELTZER, H. Y., D'HONDT, P., COSYNS, P. \& BLOCKX, P. 1995. Effects of serotonin precursors on the negative feedback effects of glucocorticoids on hypothalamic-pituitary-adrenal axis function in depression. Psychoneuroendocrinology, 20, 149-67.

MARKUS, C. R. 2008. Dietary amino acids and brain serotonin function; implications for stress-related affective changes. Neuromolecular Med, 10, 247-58.

MARKUS, C. R. 2013. Interaction between the 5-HTTLPR genotype, impact of stressful life events, and trait neuroticism on depressive symptoms in healthy volunteers. Psychiatr Genet, 23, 108-16.

MARKUS, C. R. \& CAPELLO, A. E. 2012. Contribution of the 5-HTTLPR gene by neuroticism on weight gain in male and female participants. Psychiatr Genet, 22, 27985.

MARKUS, C. R. \& DE RAEDT, R. 2011. Differential effects of 5-HTTLPR genotypes on inhibition of negative emotional information following acute stress exposure and tryptophan challenge. Neuropsychopharmacology, 36, 819-26. 
MARKUS, C. R. \& FIRK, C. 2009. Differential effects of tri-allelic 5-HTTLPR polymorphisms in healthy subjects on mood and stress performance after tryptophan challenge. Neuropsychopharmacology, 34, 2667-74.

MARKUS, C. R., FIRK, C., GERHARDT, C., KLOEK, J. \& SMOLDERS, G. F. 2008. Effect of different tryptophan sources on amino acids availability to the brain and mood in healthy volunteers. Psychopharmacology (Berl), 201, 107-14.

MARKUS, C. R., JONKMAN, L. M., CAPELLO, A., LEINDERS, S. \& HUSCH, F. 2015. Sucrose preload reduces snacking after mild mental stress in healthy participants as a function of 5-hydroxytryptamine transporter gene promoter polymorphism. Stress, 18, 149-59.

MARKUS, C. R., JONKMAN, L. M., LAMMERS, J. H., DEUTZ, N. E., MESSER, M. H. \& RIGTERING, N. 2005. Evening intake of alpha-lactalbumin increases plasma tryptophan availability and improves morning alertness and brain measures of attention. Am J Clin Nutr, 81, 1026-33.

MARKUS, C. R., OLIVIER, B. \& DE HAAN, E. H. 2002. Whey protein rich in alphalactalbumin increases the ratio of plasma tryptophan to the sum of the other large neutral amino acids and improves cognitive performance in stress-vulnerable subjects. Am J Clin Nutr, 75, 1051-6.

MARKUS, C. R., OLIVIER, B., PANHUYSEN, G. E., VAN DER GUGTEN, J., ALLES, M. S., TUITEN, A., WESTENBERG, H. G., FEKKES, D., KOPPESCHAAR, H. F. \& DE HAAN, E. E. 2000. The bovine protein alpha-lactalbumin increases the plasma ratio of tryptophan to the other large neutral amino acids, and in vulnerable subjects raises brain serotonin activity, reduces cortisol concentration, and improves mood under stress. Am J Clin Nutr, 71, 1536-44.

MARKUS, C. R., PANHUYSEN, G., JONKMAN, L. M. \& BACHMAN, M. 1999. Carbohydrate intake improves cognitive performance of stress-prone individuals under controllable laboratory stress. Br J Nutr, 82, 457-67.

MARKUS, C. R., PANHUYSEN, G., TUITEN, A., KOPPESCHAAR, H., FEKKES, D. \& PETERS, M. L. 1998. Does carbohydrate-rich, protein-poor food prevent a deterioration of mood and cognitive performance of stress-prone subjects when subjected to a stressful task? Appetite, 31, 49-65.

MARKUS, C. R., ROGERS, P. J., BROUNS, F. \& SCHEPERS, R. Submitted. Eating dependence and weight gain; no human evidence for a "suggar-addiction"model of overweight. Submitted to Addiction.

MARKUS, C. R., VERSCHOOR, E., FIRK, C., KLOEK, J. \& GERHARDT, C. C. 2010. Effect of tryptophan-rich egg protein hydrolysate on brain tryptophan availability, stress and performance. Clin Nutr, 29, 610-6.

MARKUS, C. R., VERSCHOOR, E. \& SMEETS, T. 2012. Differential effect of the 5-HTT gene-linked polymorphic region on emotional eating during stress exposure following tryptophan challenge. J Nutr Biochem, 23, 410-6.

MCEWEN, B. S. 2007. Physiology and neurobiology of stress and adaptation: central role of the brain. Physiol Rev, 87, 873-904.

MCEWEN, B. S. \& WINGFIELD, J. C. 2003. The concept of allostasis in biology and biomedicine. Horm Behav, 43, 2-15.

MELLBIN, T. \& VUILLE, J. C. 1989a. Further evidence of an association between psychosocial problems and increase in relative weight between 7 and 10 years of age. Acta Paediatr Scand, 78, 576-80.

MELLBIN, T. \& VUILLE, J. C. 1989b. Rapidly developing overweight in school children as an indicator of psychosocial stress. Acta Paediatr Scand, 78, 568-75. 
MILLER, R., WANKERL, M., STALDER, T., KIRSCHBAUM, C. \& ALEXANDER, N. 2012. The serotonin transporter gene-linked polymorphic region (5-HTTLPR) and cortisol stress reactivity: a meta-analysis. Mol Psychiatry.

MILLER, R., WANKERL, M., STALDER, T., KIRSCHBAUM, C. \& ALEXANDER, N. 2013. The serotonin transporter gene-linked polymorphic region (5-HTTLPR) and cortisol stress reactivity: a meta-analysis. Mol Psychiatry, 18, 1018-24.

MORGAN, J. E., HAMMEN, C. \& LEE, S. S. 2016. Parental Serotonin Transporter Polymorphism (5-HTTLPR) Moderates Associations of Stress and Child Behavior With Parenting Behavior. J Clin Child Adolesc Psychol, 1-12.

MORMEDE, P., COURVOISIER, H., RAMOS, A., MARISSAL-ARVY, N., OUSOVA, O., DESAUTES, C., DUClOS, M., CHAOUlOFF, F. \& MOISAN, M. P. 2002. Molecular genetic approaches to investigate individual variations in behavioral and neuroendocrine stress responses. Psychoneuroendocrinology, 27, 563-83.

MUELLER, A., BROCKE, B., FRIES, E., LESCH, K. P. \& KIRSCHBAUM, C. 2010. The role of the serotonin transporter polymorphism for the endocrine stress response in newborns. Psychoneuroendocrinology, 35, 289-96.

MUNAFO, M. R., BROWN, S. M. \& HARIRI, A. R. 2008. Serotonin transporter (5HTTLPR) genotype and amygdala activation: a meta-analysis. Biol Psychiatry, 63, 852-7.

NEUMEISTER, A., HU, X. Z., LUCKENBAUGH, D. A., SCHWARZ, M., NUGENT, A. C., BONNE, O., HERSCOVITCH, P., GOLDMAN, D., DREVETS, W. C. \& CHARNEY, D. S. 2006. Differential effects of 5-HTTLPR genotypes on the behavioral and neural responses to tryptophan depletion in patients with major depression and controls. Arch Gen Psychiatry, 63, 978-86.

NEUMEISTER, A., KONSTANTINIDIS, A., STASTNY, J., SCHWARZ, M. J., VITOUCH, O., WILLEIT, M., PRASCHAK-RIEDER, N., ZACH, J., DE ZWAAN, M., BONDY, B., ACKENHEIL, M. \& KASPER, S. 2002. Association between serotonin transporter gene promoter polymorphism (5HTTLPR) and behavioral responses to tryptophan depletion in healthy women with and without family history of depression. Arch Gen Psychiatry, 59, 613-20.

OROSCO, M., ROUCH, C., BESlot, F., FEURTE, S., REGNAUlT, A. \& DAUGE, V. 2004. Alpha-lactalbumin-enriched diets enhance serotonin release and induce anxiolytic and rewarding effects in the rat. Behav Brain Res, 148, 1-10.

PENLEY, J. A., TOMAKA, J. \& WIEBE, J. S. 2002. The association of coping to physical and psychological health outcomes: a meta-analytic review. J Behav Med, 25, 551603.

ROBERTS, J. G., BROWNE, G., STREINER, D., BYRNE, C., BROWN, B. \& LOVE, B. 1987. Analyses of coping responses and adjustment: stability of conclusions. Nurs Res, 36, 94-7.

ROBERTS, S. B. \& KENDLER, K. S. 1999. Neuroticism and self-esteem as indices of the vulnerability to major depression in women. Psychol Med, 29, 1101-9.

ROGERS, P. J. 1995. Food, mood and appetite. Nutr Res Rev, 8, 243-69.

ROY, M., TAPADIA, M. G., JOSHI, S. \& KOCH, B. 2014. Molecular and genetic basis of depression. J Genet, 93, 879-92.

SCHEPERS, R. \& MARKUS, C. R. 2015. Gene x cognition interaction on stress-induced eating: effect of rumination. Psychoneuroendocrinology, 54, 41-53.

SHARPlEY, C. F., PALANISAMY, S. K., GLYDE, N. S., DillingHAM, P. W. \& AGNEW, L. L. 2014. An update on the interaction between the serotonin transporter promoter variant (5-HTTLPR), stress and depression, plus an exploration of nonconfirming findings. Behav Brain Res, 273, 89-105. 
SIMANSKY, K. J. 1996. Serotonergic control of the organization of feeding and satiety. Behav Brain Res, 73, 37-42.

SPRING, B., CHIODO, J. \& BOWEN, D. J. 1987. Carbohydrates, tryptophan, and behavior: a methodological review. Psychol Bull, 102, 234-56.

STECKLER, T., KALIN, N. H. \& REUL, J. M. H. M. 2005. Handbook of stress and the brain, Netherlands, Elsevier.

STEPTOE, A., HAMER, M. \& CHIDA, Y. 2007. The effects of acute psychological stress on circulating inflammatory factors in humans: a review and meta-analysis. Brain Behav Immun, 21, 901-12.

THOMASON, M. E., HENRY, M. L., PAUL HAMILTON, J., JOORMANN, J., PINE, D. S., ERNST, M., GOLDMAN, D., MOGG, K., BRADLEY, B. P., BRITTON, J. C., LINDSTROM, K. M., MONK, C. S., SANKIN, L. S., LOURO, H. M. \& GOTLIB, I. H. 2010. Neural and behavioral responses to threatening emotion faces in children as a function of the short allele of the serotonin transporter gene. Biol Psychol, 85, 38-44.

UHER, R. \& MCGUFFIN, P. 2008. The moderation by the serotonin transporter gene of environmental adversity in the aetiology of mental illness: review and methodological analysis. Mol Psychiatry, 13, 131-46.

URSIN, H. \& OLFF, M. 1993. Psychobiology of coping and defence strategies. Neuropsychobiology, 28, 66-71.

VAN DALFSEN, J. H. \& MARKUS, C. R. 2015. Interaction between 5-HTTLPR genotype and cognitive stress vulnerability on sleep quality: effects of sub-chronic tryptophan administration. Int $J$ Neuropsychopharmacol, 18.

VAN DER MEER, D., HOEKSTRA, P. J., ZWIERS, M., MENNES, M., SCHWEREN, L. J., FRANKE, B., HESLENFELD, D. J., OOSTERLAAN, J., FARAONE, S. V., BUITELAAR, J. K. \& HARTMAN, C. A. 2015. Brain Correlates of the Interaction Between 5-HTTLPR and Psychosocial Stress Mediating Attention Deficit Hyperactivity Disorder Severity. Am J Psychiatry, 172, 768-75.

VAN PRAAG, H. M. 2004. Can stress cause depression? Prog Neuropsychopharmacol Biol Psychiatry, 28, 891-907.

VERSCHOOR, E. \& MARKUS, C. R. 2011. Affective and neuroendocrine stress reactivity to an academic examination: influence of the 5-HTTLPR genotype and trait neuroticism. Biol Psychol, 87, 439-49.

WANKERL, M., ZYRIAX, B. C., BONDY, B., HINKELMANN, K., WINDLER, E. \& OTTE, C. 2010. Serotonin transporter gene-linked polymorphic region (5-HTTLPR) and diurnal cortisol: A sex by genotype interaction. Biol Psychol, 85, 344-6.

WATSON, D. \& CLARK, L. A. 1984. Negative affectivity: the disposition to experience aversive emotional states. Psychol Bull, 96, 465-90.

WAY, B. M. \& TAYLOR, S. E. 2010. The serotonin transporter promoter polymorphism is associated with cortisol response to psychosocial stress. Biol Psychiatry, 67, 487-92.

WITTEKIND, A. \& WALTON, J. 2014. Worldwide trends in dietary sugars intake. Nutr Res Rev, 27, 330-45.

WOLRAICH, M. L., WILSON, D. B. \& WHITE, J. W. 1995. The effect of sugar on behavior or cognition in children. A meta-analysis. JAMA, 274, 1617-21.

WURTMAN, R. J. 1984. Effects of foods and nutrients on brain neurotransmitters. Curr Concepts Nutr, 13, 103-12.

WURTMAN, R. J. 2011. Non-nutritional uses of nutrients. Eur J Pharmacol, 668 Suppl 1, S10-5.

WURTMAN, R. J. \& WURTMAN, J. J. 1984. Nutrients, neurotransmitter synthesis, and the control of food intake. Res Publ Assoc Res Nerv Ment Dis, 62, 77-86. 
WURTMAN, R. J., WURTMAN, J. J., REGAN, M. M., MCDERMOTT, J. M., TSAY, R. H. \& BREU, J. J. 2003. Effects of normal meals rich in carbohydrates or proteins on plasma tryptophan and tyrosine ratios. Am J Clin Nutr, 77, 128-32.

ZIAUDDEEN, H., CHAMBERLAIN, S. R., NATHAN, P. J., KOCH, A., MALTBY, K., BUSH, M., TAO, W. X., NAPOlitANO, A., SKEGGS, A. L., BROOKE, A. C., CHEKE, L., CLAYTON, N. S., SADAF FAROOQI, I., O'RAHILLY, S., WATERWORTH, D., SONG, K., HOSKING, L., RICHARDS, D. B., FLETCHER, P. C. \& BULLMORE, E. T. 2013. Effects of the mu-opioid receptor antagonist GSK1521498 on hedonic and consummatory eating behaviour: a proof of mechanism study in binge-eating obese subjects. Mol Psychiatry, 18, 1287-93.

ZIAUDDEEN, H. \& FLETCHER, P. C. 2013a. Central nervous system biomarkers for antiobesity drug development. Drug Discov Today, 18, 1282-91.

ZIAUDDEEN, H. \& FLETCHER, P. C. 2013b. Is food addiction a valid and useful concept? Obes Rev, 14, 19-28.

ZOCCOLA, P. M. \& DICKERSON, S. S. 2012. Assessing the relationship between rumination and cortisol: a review. J Psychosom Res, 73, 1-9. 

